\title{
Are prescribed fire and thinning dominant processes affecting snag occurrence at a landscape scale?
}

\author{
Stanley J. Zarnoch ${ }^{\mathrm{a}^{*}}$, John I. Blake ${ }^{\mathrm{b1}}$, Bernard R. Parresol ${ }^{\mathrm{c}}$ \\ ${ }^{a}$ USDA Forest Service, USDA Forest Service, Southern Research Station, Lehotsky Hall, \\ Clemson University, Clemson, SC 29634, USA \\ ${ }^{\mathrm{b}}$ USDA Forest Service, USDA Forest Service, New Ellenton, SC, 29809, USA \\ ${ }^{c}$ USDA Forest Service, USDA Forest Service, Pacific Northwest Research Station, Portland, OR, \\ 97204, USA
}

* Corresponding author. Tel.: +1 864576 8188. E-mail addresses: szarnoch@fs.fed.us (S.J. Zarnoch), jblake@fs.fed.us (J.I. Blake).

${ }^{1}$ Tel.: +1 8037258721 


\section{ABSTRACT}

Snags are standing dead trees that are an important component in the nesting habitat of birds and other species. Although snag availability is believed to limit populations in managed and non-managed forests, little data are available to evaluate the relative effect of stand conditions and management on snag occurrence. We analyzed point sample data from an intensive forest inventory within an 80,000 hectare landscape for four major forest types to support the hypotheses that routine low-intensity prescribed fire would increase, and thinning would decrease, snag occurrence. We employed path analysis to define a priori causal relationships to determine the direct and indirect effects of site quality, age, relative stand density index and fire for all forest types and thinning effects for loblolly pine and longleaf pine. Stand age was an important direct effect for loblolly pine, mixed pine-hardwoods and hardwoods, but not for longleaf pine. Snag occurrence in loblolly pine was increased by prescribed fire and decreased by thinning which confirmed our initial hypotheses. Although fire was not important in mixed pine-hardwoods, it was for hardwoods but the relationship depended on site quality. For longleaf pine the relative stand density index was the dominant variable affecting snag occurrence, which increased as the density index decreased. Site quality, age and thinning had significant indirect effects on snag occurrence in longleaf pine through their effects on the density index. Although age is an important condition affecting snag occurrence for most forest types, path analysis revealed that fire and density management practices within certain forest types can also have major beneficial effects, particularly in stands less than 60 years old.

Key Words: cavity-nesting species, forest management, silviculture, southeastern United States, wildlife habitat 


\section{Introduction}

Wildlife habitat suitability metrics inferred from vegetation composition and structure can be reliable indicators of species occurrence and an important tool for making population assessments (Milspaugh and Thompson 2008). The availability of standing dead trees, commonly known as snags, to primary and secondary avian cavity nesting species, particularly large snags, can influence species presence or absence in a variety of forests in numerous biomes (Marchetti, 2004, Kroll et al., 2012). The southeastern U.S. includes several such biomes with snag-dependent avian and mammal species of conservation concern (e.g., Kilgo and Vukovich 2014). However, snag occurrence is highly variable within forests of the region (Rosenberg et al. 1988, Land et al. 1989, Moorman et al. 1999). Understanding the processes influencing patterns of snag abundance is important for prediction and assessment of habitat. Natural processes, such as high stem densities, severe wildfires, lightning, storms, diseases and insects, control snag recruitment while wind and decay control loss rates of snags. Although direct process modeling of snag occurrence using all known and unknown causal factors is impractical, the processes may be associated with more readily collected and widely available stand variables such as vegetation composition, age, site quality and stand density.

In forests managed for forest products and wildlife habitat, overstory thinning and prescribed fire are potentially important factors affecting landscape variation of snag occurrence. The density of snags was negatively affected by thinning in Douglas-fir (Pseudotsuga menzesii Franco.) in Oregon (Hagar et al. 1996), mixed-species forests of Maine (Garber et al. 2005), and young pine stands (<35 years) in North Carolina (Homyack et al. 2011). Edworthy and Martin (2013) found reductions in post-harvest snag persistence in aspen forests in British Columbia. Zarnoch et al. (2013) observed a reduction in the length of time snags stood following a stand 
thinning compared with snags in non-thinned stands. A commonality among these studies is the potential for increased wind-loading on snags that can cause them to fall sooner after thinning than under non-thinned conditions (Petola 2006). In contrast, prescribed fire can increase the number of snags due to overstory tree mortality following burning (Menges and Deyrup 2001, Sullivan et al. 2003, Yaussy and Waldrop 2010). However, there is limited information on how low-intensity prescribed fire affects snag occurrence across a range of forest types, ages and fire regimes.

Experimental evidence from diverse studies for a negative impact of thinning on residual snag density and persistence, and the positive effects of prescribed fire on snag-recruitment, raises the question of the importance of these effects at a landscape level. Specifically, are thinning and prescribed fire dominant processes that directly or indirectly affect snag occurrence within several different forest types? Second, how important are the direct effects of site index, age and stand density relative to any impacts of fire and thinning? To address these questions and to confirm the hypotheses that thinning and fire are dominant processes, we constructed an $a$ priori path model to represent the hypothesized direct and indirect effects of these variables on snag occurrence (Kline 1998). We used observations of snag occurrence on forest inventory point samples distributed over several common forest types on an 80,000 hectare (ha) forest landscape. In addition, we created logistic models of snag occurrence for each forest type to provide predictive models as functions of stand age, site and density and the thinning and prescribed fire management variables.

\section{Methods}

The study was conducted at the U. S. Department of Energy's Savannah River Site (SRS), a National Environmental Research Park in Aiken and Barnwell counties, South Carolina in the Upper Coastal Plain and Sandhills physiographic provinces (Kilgo and Blake 2005). The 
site has a long history of agriculture cultivation and forest harvest typical of the region that dates from the $18^{\text {th }}$ century prior to Department of Energy control in 1951.

\subsection{Forest Vegetation Point Sample Data and Treatment History}

During May through September 2010, we measured live trees and snags on 1680 point samples (Husch, et al. 1993) located systematically across the SRS resulting in about one point per 48 ha of forest. From the center of each point we used a 2.3 factor prism, or occasionally a 1.15 factor prism if fewer than 5 live trees were in the 2.3 factor count, to determine basal area (BA) and density for all live trees and snags. Point samples without live trees in the count (recently harvested and young stands) were removed from the database, which reduced the dataset to 1603 point samples. We further eliminated slash pine (Pinus elliottii) and cypresstupelo (Taxodium distichum-Nyssa biflora) dominated point samples due to limited sample size or lack of management, respectively. We measured all tree diameters (DBH) and identified species (Parresol and Blake 2010). A total of 459 snags were inventoried on 286 of the 1454 sample points (Table 1).

We defined snag occurrence at a sample point as the presence of at least one snag in the prism count. Large snag occurrence was the presence of at least one snag greater than or equal to $25 \mathrm{~cm} \mathrm{DBH}$. The forest type assigned to each point sample corresponds to common southeastern forest types. Sample points having at least $80 \%$ of their basal area in longleaf pine (Pinus palustris), or loblolly pine (P. taeda), were analyzed as separate forest types. These pinedominated forests are commonly thinned and burned periodically. Point samples of mixed pinehardwoods (21-79\% pine) and hardwoods (20\% or fewer pines) were also treated as separate forest types. Hardwoods stands are rarely thinned, but they are burned periodically because they reside within the pine-dominated landscape which is burned. 
We obtained stand age at each sample point from the SRS forest vegetation database. We cross-checked and corrected age using the previous (2001) inventory that included direct core aging of trees at 629 sample points. Age ranged from 2 to 123 years for the 1454 sample points. Site quality, based on standardized dominant tree height at age 50 years (site index, $S I$ ), was determined using a depth to groundwater, soils and land use history model (Edwards and Parresol 2012) and ranged from 13 to $38 \mathrm{~m}$. The relative stand density index (RSDI) was computed following Woodall et al. (2005). First, stand density index (SDI) for each sample point was calculated using the summation method as

$$
S D I=\sum_{i=1}^{n} T F_{i}\left(\frac{D B H_{i}}{25}\right)^{1.6}
$$

where $D B H_{i}=\mathrm{DBH}(\mathrm{cm})$ for tree $i, \mathrm{n}=$ number of prism trees in the sample point, and $T F_{i}=$ the expansion factor for the $i^{\text {th }}$ tree. The sample point mean specific gravity index $\left(S G_{m}\right)$ is then calculated as

$$
S G_{m}=\frac{1}{n} \sum_{i=1}^{n} S G_{i}
$$

where $S G_{i}=$ species specific gravity for tree $i$. Species specific gravities at 12 percent moisture content volume and oven-dry weight were obtained from the FIA DataMart http://www.fia.fs.fed.us/tools-data (Woudenberg et al. 2010). We calculated the maximum stand density index for pure and mixed species stands at the $99 \%$ level ( $S D I_{99}$ ) using the Woodall et al. (2005) equation

$$
S D I_{99}=2057.3-2098.6\left(S G_{m}\right)
$$

The RSDI for each plot is then expressed as

$$
R S D I=\frac{S D I}{S D I_{99}}
$$


The treatment history for each sample point was obtained from the SRS land management database that includes prescribed fire history since 1971 and thinning history since 1996 . The area of SRS treated annually with low-intensity surface prescribed fires ranged from approximately 5,000 to 15,000 ha. Very little prescribed burning was done between 1951 and 1976, so the database captures most of the burning conducted for these sample points. Approximately 1700 to 2800 ha of thinning were completed annually from 1980 to 2010 in pine and occasionally mixed pine-hardwoods stands. When stands are thinned, the smaller and poor stem quality materials are removed preferentially subject to the residual density or spacing standards. As stands age the residual stocking standard is lower.

Fire history was formulated as an integrated continuous variable representing the influence of the number of fires since establishment (range 0 to 9 ) and time since each fire ( 0.5 to 39 years). We created a fire component for the time weighted influence of each fire as

$f_{i j}=\left(1+e^{a+b y_{i}}\right)^{-1}$ if fire $\mathrm{j}$ occurred before 2010

$f_{i j}=0.5 \quad$ if fire $\mathrm{j}$ occurred in 2010

where $f_{i j}$ is the fire component due to fire $j$, and $y_{i}$ is the number of years since fire $j$ occurred on sample point $i$. The composite fire index is then $F I_{i}=\sum_{i=1}^{n_{i}} f_{i j}$ where $n_{i}=$ number of fires on sample point $i$. Thus, $F I_{i}$ is a function of the number of fires where recent fires are weighted larger than those in the past. For instance, a sample point burned in 2009 and 2004 would have a larger $F I_{i}$ than a sample point with burns in 2000 and 1995 . The parameter " $a$ " was fixed at -6 , and " $b$ " at 1 which reflects a survival probability of snags similar to previous work by Menges and Deyrup (2001), Sullivan et al. (2003), Yaussy and Waldrop (2010), and Zarnoch et al. (2013) such that the half-life from equation 5a was 6 years, which included 2 years for tree death to 
occur. The fire index reduced the fire effect from two categorical variables to one continuous variable. This approach eliminated many categorical interaction terms and problems with extracting direct and indirect effects in path analysis that would have made interpretation of results more difficult. The thinning history for each sample point consists of time since last thinning ( 0.5 to $14+$ years $)$ prior to the 2010 inventory. A continuous thinning index $\left(T I_{i}\right)$ was calculated in the same manner as the $F I_{i}$. Since thinning is done over much longer periodic intervals $(10+$ years $)$ very few $T I_{i}$ values included more than one thinning event.

\subsection{Path Analysis}

Path analysis is a technique used to quantify and compare the strengths of direct and indirect causal effects among a set of variables of a particular biological system by simultaneously solving a set of linear equations (Kline 1998). This will be explained later in this section. We defined a priori a path model to describe snag occurrence and address the initial hypotheses regarding the direct and indirect effects of prescribed fire and thinning as well as other stand variables (Fig. 1). Following standard terminology, $A G E, S I$ and $T I$ are exogenous variables that are related via a covariance term (indicated by arrows with both ends pointed in Fig. 1). Exogenous variables are not required to be normally distributed (Kline 1998). The FI and RSDI are endogenous mediating variables, in that they are both influenced by other variables and potentially mediate the influence of $A G E, S I$ and $T I$ on snag occurrence. To satisfy the assumptions in path modeling, these variables should be normally distributed. Snag occurrence is purely an endogenous dichotomous $(0,1)$ variable.

Direct paths are represented by arrows connecting variables and snag occurrence that do not pass through another variable $(O S, O D, O F, O T, O A)$. Indirect paths are represented by arrows entering and leaving other variables. For example, the indirect paths to snag occurrence for $A G E$ 
are $O F^{*} F A$ and $O D^{*} D A$, which can be compared to the direct path of $A G E$ to snag occurrence $(O A)$. We considered $A G E$ as a dominant variable since many of the processes contributing to tree mortality are more likely to be dependent upon age. We hypothesized that $S I$ has a minor effect on snag occurrence which would be expressed through the RSDI. The FI is hypothesized to have a direct positive effect on snag occurrence while it is also positively affected by $A G E$ since prescribed fire is delayed in young stands to minimize damage and older stands incur more burns over time. Age directly influences $R S D I$, but does not directly influence $T I$ in pinedominated forest types. Once stands reach sufficient size or value they can be thinned, but age itself does not control thinning. Thinning can directly affect $R S D I$ and subsequently snag occurrence can be mediated through RSDI.

Path analysis was conducted with M-PLUS software (Muthén and Muthén 2011) using the maximum likelihood estimation method for the loblolly pine, longleaf pine, mixed pinehardwoods and hardwoods forest types. All endogenous variables were normally distributed except $F I$. The $F I$ variable is highly skewed to the right due to the large number of observations with none or few burns that occurred decades prior to the inventory. In order to normalize FI, transformations were performed but they had little effect. We therefore randomly removed observations with $F I$ values between 0 and 0.15 from each forest type. Approximately $85 \%$, $70 \%, 75 \%$ and $90 \%$ of the points in this range were removed for loblolly pine, longleaf pine, mixed pine-hardwoods and hardwoods, respectively. This procedure normalized FI, but had little effect on the means of the other variables (Table 2). We re-scaled $A G E$ and $S I$ by dividing by 100 to keep these variables within the same order of magnitude as the others. The main variables were centered by subtracting the means to reduce multicollinearity effects. Bivariate plots were examined among all continuous variables with either direct or indirect paths to evaluate whether 
transformation would improve the linear relationship. No relationships exhibited sufficient nonlinear patterns to justify a transformation of the variable.

We compared the sign and magnitude of all standardized direct path coefficients whose pvalues were $\leq 0.10$. A standardized path coefficient is a partial correlation coefficient, ranges between positive and negative 1 and indicates a level of association between the two variables. Each indirect path coefficient was computed as the product of its individual paths (e.g., $O F^{*} F A$ ) while the total indirect effect was the sum of the individual paths (e.g., $\left(O F^{*} F A\right)+\left(O D^{*} D A\right)$. The total causal effect for $A G E$ is then the sum of the direct effect plus the indirect effect (e.g. $\left.(O A)+\left(O F^{*} F A\right)+\left(O D^{*} D A\right)\right)$. We examined the logistic model results (below) for logical interactions between the variables that could be justified on biological or physical grounds and then revised the path model accordingly (Fig. 2 and Fig. 3). The new alternative path model was compared against the original model based on the Akaike's Information Criteria (AIC) fit statistics (Muthén and Muthén 2011).

\subsection{Predicting Occurrence Probabilities for a Fixed Area}

We developed logistic models for all snags and large snags for each forest type to predict the probability that a sample point (not a fixed area) would have at least one snag and to identify important interactions among variables that justify revision of the path model. Later this probability with a sample point basis was converted to a fixed area of 0.25 ha. Independent stand variables consisted of $A G E, S I$ and $R S D I$ while management variables were $F I$ and $T I$ in the loblolly pine and longleaf pine forest types and $F I$ in the mixed pine-hardwoods and hardwoods forest types. In addition, all 2-way interactions of all variables were included in the initial full model. PROC Logistic (SAS 2004) was used for the modeling with the backward elimination option performed in a stepwise manner using a p-value of $\leq 0.10$ for the elimination of a 
variable. All main effect variables were retained regardless of $\mathrm{p}$-value if their interaction term was significant. The preferred predictive model was selected based on the relative AIC, the maximum re-scaled $r^{2}$ and the Hosmer-Lemeshow fit statistic. Although we contemplated the use of more complex alternate approaches such as the Information Theoretic-AIC, we used the stepwise backward elimination because it is well known and, thus, would not detract from our main purpose of introducing path analysis. Moreover, it selected from only five main effect variables that had meaningful biological relevance to snag occurrence, resulting in a relatively small number of tentative models for consideration.

We estimated a likelihood index of at least one snag on a fixed area for each forest type conditioned on stand and management variables based on the final model. This facilitated comparison of likelihood estimates among forest types and their change with conditions. To estimate the likelihood index for a fixed area $\left(I_{\mathrm{A}}\right)$ based on stand and management variables, we calculated the effective plot size $\left(A_{q m d}\right)$ corresponding to the prism basal area factor $(\mathrm{BAF})$ and quadratic mean diameter $\left(D B H_{q m d}\right)$ of the forest type sample population using the standard formula of limiting distance $\left(L D_{q m d}\right)$ (Husch et al. 1993)

$$
L D_{q m d}=\sqrt{\frac{0.25}{B A F}} D B H_{q m d}
$$

Then the corresponding area for the $\mathrm{DBH}_{q m d}$ was

$$
A_{q m d}=3.14\left(L D_{q m d}\right)^{2}
$$

The resulting $A_{q m d}$ was the effective sample area for the sample population with the calculated $D B H_{q m d .}$. The $I_{\mathrm{A}}$ of a snag on a fixed area of any size $Z$ (ha) with given stand and management conditions is

$$
I_{A}=1-(1-P)^{X}
$$


where $P$ is the probability of snag occurrence obtained from the logistic model and $X=Z$ / $A_{\text {qmd }}$ is the number of units of $A_{\text {qmd }}$ on the selected area $Z$. This assumes that the probability of at least one snag on $X$ areas of size $A_{q m d}$ is independent which is justifiable since the area is conditioned on the same stand and management variables. We established $Z$ as 0.25 ha which provides a full range of $I_{\mathrm{A}}$ values between 0.05 and 0.95 .

\section{Results}

\subsection{Path Analysis}

We estimated path model standardized coefficients for the probability of occurrence of one snag or more, and of one large snag or more, for all forest types (Table 3). For loblolly pine and mixed pine-hardwoods, the models were not improved by inclusion of interaction terms based on the AIC values. The AIC values were substantially improved by including the AGE $x$ RSDI interaction for the longleaf pine and the SI x FI interaction for the hardwoods path models (Fig. 2 and Fig. 3). Thus, these path models with interaction terms were selected for the direct and indirect effects of the main variables in longleaf pine and hardwoods. Several results of the stand variables on snag occurrence were similar among forest types for the two snag size classes (Table 3). We detected no significant direct effects of $S I$ on snag occurrence for any forest type or snag size class. $R S D I$ had no significant direct effect on snag occurrence except in longleaf pine and large loblolly pine. Stand $A G E$ had a significant and positive direct effect except in the all size class of longleaf pine. The standardized direct path coefficients for $A G E$ were larger than any other variable in all forest types except longleaf pine.

Path analysis revealed direct effects of fire and thinning relative to stand variables. For loblolly pine, $T I$ negatively influenced snag occurrence for all snags as hypothesized, but not for large snags, and was about $60 \%$ of the direct effect of $A G E$. As hypothesized, FI positively 
affected snag occurrence in both snag size classes for loblolly pine with standardized coefficients being about half the $A G E$ effect. In contrast, for longleaf pine neither $F I$ nor $T I$ showed significant direct effects for snag occurrence. The direct effect of $R S D I$ was negative and dominated snag occurrence in both snag size classes for longleaf pine. In the mixed pinehardwoods forest type $F I$ did not have a significant direct effect on snag occurrence, which was influenced only by $A G E$. In the hardwoods forest type, the negative $F I$ direct effect was comparable, but opposite of the positive $A G E$ effect in both snag size classes. Although this is contrary to our hypothesis, the negative SI $x F I$ interaction reveals that at low SI, FI actually results in an increase in snag occurrence.

In general, the magnitude and significance of the direct effect path coefficients of SI to RSDI, $A G E$ to $R S D I, T I$ to $R S D I$ and $A G E$ to $F I$ varied between forest types (Table 3). The loblolly pine and longleaf pine path coefficients of $A G E$ to $R S D I$ and $T I$ to $R S D I$ were negative while $A G E$ to $F I$ was positive as expected. As $A G E$ and $T I$ increased, $R S D I$ decreased. In longleaf pine, the direct path from SI to $R S D I$ was negative indicating that as $S I$ increased, $R S D I$ declined. With the mixed pine-hardwoods forest type no other direct path coefficients were significant. In the hardwoods forest type the path coefficient from $A G E$ to $R S D I$ showed that as $A G E$ increased $R S D I$ increased.

The indirect paths for loblolly pine, mixed pine-hardwoods and hardwoods were not significant, and thus interpretation of the relative size of their total effects is related to their direct path coefficients. In longleaf pine, the indirect paths for $S I, A G E$ and $T I$ were significant, which was entirely related to the indirect paths from these variables through $R S D I$ or the AGE $x$ RSDI interaction (Table 4). The indirect coefficients were generally small relative to the $R S D I$ variable 
in the all snag class. However, the $T I$ and $A G E$ indirect coefficients in the large snag class were much larger relative to the RSDI variable.

\subsection{Predicting Occurrence Probabilities and Likelihood Indices for a Fixed Area}

The average snag density varied considerably among the forest types with loblolly pine being 18.4, longleaf pine 11.7, mixed pine-hardwoods 39.5 and hardwoods 33.6 snags ha $^{-1}$. Large snags were very common in the mixed pine-hardwoods and hardwoods forest types, being 79$93 \%$ of all snags while in loblolly pine and longleaf pine they were only about 40 and $60 \%$. Regression parameters and significance levels were obtained for the all and large snag logistic snag occurrence models (Table 5). The maximum re-scaled $r^{2}$ values were low, but expected when fitting logistic models for relatively rare events using point samples that represent small areas. The maximum re-scaled $\mathrm{r} 2$ values were generally greater for the large snag models than for the all snag models.

The all snag loblolly pine model included $A G E$, SI and $F I$, all with positive parameters, and the AGE $x S I$ interaction. The $T I$ was not significant in the all snags predictive model, which contrasts with the path model. $F I$ and $A G E$ were positively associated with the probability of large snag occurrence between high and low $F I$ values at the average $S I$ of $25.9 \mathrm{~m}$ (Fig. 4). In longleaf pine the predictive models for all and large snags are similar with respect to the effect of the stand variables, except $S I$, as well as the strong interaction between $A G E \times R S D I$, the effect of $T I$ (positive), and the interaction between TI $x$ RSDI. Thinning reduces RSDI and lower RDSI values are correlated to increase snag occurrence in longleaf pine. The highly significant coefficients for $R S D I$ are consistent between the path and predictive modeling approach. The relationship of large snag occurrence with $A G E$ is complex due to the $A G E x R S D I$ interaction. In longleaf pine $<60$ years, which represents predominately planted stands, at the average $T I$ of 
0.175 and $S I$ of $23.1 \mathrm{~m}$, snag occurrence increases as $R S D I$ declines, whereas in older, largely natural stands, the $R S D I$ relationship is reversed (Fig. 5).

For the mixed pine-hardwoods forest type, a strong positive relationship existed between $A G E$ and snag occurrence. Similar to path analysis results, $F I$ was not related to snag occurrence and was only retained in the predictive model as a result of the marginally significant $A G E x F I$ interaction term. In the hardwoods forest type, the predictive analysis parallels the path analysis in the large snag class. Although $A G E$ and $F I$ are related to snag occurrence, a significant interaction existed between SI x FI which altered the simple effect of $F I$. When $S I$ was low (20 m), FI had a strong positive influence on snag occurrence (Fig. 6). If $S I$ was high (30 m), the relationship was negative (Fig. 7).

\section{Discussion}

The path analysis confirmed the expectation that low-intensity prescribed fire was a dominant process contributing to increased snag occurrence for loblolly pine, the most widely distributed forest species in the southern U.S. Selective thinning was also an important process affecting snag occurrence, but only when considering snags contained in all size classes, including those small snags not generally as important to primary cavity nesting species as large snags (Lohr et al. 2002). The proposed mechanistic cause of additional wind-loading due to thinning is not consistent with these results (Petola 2006). The results suggest that mechanical thinning operations may simply destroy very small material and/or that smaller diameter stems are preferentially harvested. The latter operation would remove suppressed or sub-dominate trees that contribute to smaller diameter snags. Based on the results, the application of prescribed fire at intervals of 2 to 4 years can have effects on snag recruitment comparable to stand age in 
loblolly pine forests. However, age is the most important stand condition influencing large snag occurrence.

Our path model results for longleaf pine contrast dramatically with those for loblolly pine. Age was not a major variable for longleaf pine except among large snags, and neither prescribed fire nor thinning had a significant direct causal path to snag occurrence. Longleaf pine is known to be among the most fire-tolerant species in the region (Wade and Johansen, 1986). The very large path coefficients showing that snag occurrence decreased with higher stem densities is counterintuitive since thinning had no significant direct effect in the path analysis. We interpret the strong $R S D I$ relationship as a long term effect resulting from density management that contrasts with a short term or immediate effect associated with $T I$. Lower RSDI values are a consequence of thinning. Maintaining low densities in longleaf pine is a primary goal on $60 \%$ of the SRS and on many other federal and state-owned lands managed for the endangered red cockaded woodpecker (Picoides borealis). Over long periods, open stands may be more susceptible to damage from ice storms, and thinning can introduce Heterobasidion annosum root disease that can enhance mortality rates (Sullivan et al. 2003). The interaction of RSDI with $A G E$ may reflect the transition between planted stands $<60$ years versus naturally-regenerated stands $>60$ years that remain fully stocked. These older stands would be susceptible to self-thinning, as well as successive lightning strikes and bark beetle attack (Outcalt 2008).

For both mixed pine-hardwoods and hardwoods forest types, path analysis identified age as the most important causal factor leading to increased snag occurrence. Fire had no effect in the mixed pine-hardwoods forest type, which undergoes prescribed fire within the pine dominate landscape matrix. However, the fire intensity is typically low due to low dead fuel loads and sparse live shrub-grass cover (Parresol et al. 2012). Within the hardwoods forest type there is a 
clear change in the fire effect on snag occurrence with SI. At lower SI values snag occurrence increases with $F I$ whereas at higher $S I$ values the relationship is reversed (Fig. 6 and Fig. 7). We examined species composition and found only small differences (1-2\% in the dominate species) between high and low $S I$ sample points. Lower $S I$ stands are on drier upland terraces with respect to groundwater and potentially greater fire intensity than riparian forests, but that process does not explain why fire is associated with fewer snags on high SI stands.

\section{Conclusions}

The hypotheses that snag occurrence would be increased by routine low-intensity prescribed fire and decreased by thinning was confirmed for loblolly pine but varied for other forest types. Fire was not important in the longleaf pine and mixed pine-hardwoods but was for hardwoods where the relationship depended on site quality. Although age was the most important variable affecting snag occurrence for most forest types, fire and density management practices can also have major beneficial effects for certain forest types, particularly in stands less than 60 years old. Our study represents a broad range of stand and management conditions characteristic of non-industrial land management practices that predominate in these biomes. Snag average densities fall within the general range of values reported for other studies in the region for hardwoods, but they are slightly greater for pines (McComb et al.1986, Land et al. 1989, Moorman et al., 1999). Path analysis results confirm that common forest management practices in conjunction with species composition are important conditions with direct causal relationships to snag occurrence. These factors, in addition to stand age, should be considered in landscape assessments of wildlife-dependent snag habitat management (Ohmann et al. 1994, Kroll et al. 2012).

\section{Acknowledgements}


Support for this research was provided by the Department of Energy under Interagency Agreement DE-AI09-00SR22188 and by the USDA Forest Service Southern Research Station. We thank the staff of the US Forest Service Savannah River for their support to implement the inventory and Drs. Lars Brudvig and John Kilgo for manuscript suggestions.

\section{References}

Edwards, L., Parresol, B., 2012. Development of a regression kriging model conditioned with sequential Gaussian simulation to predict the spatial distribution of site index for the Savannah River Site. USDA Forest Service Savannah River Report 12-17-R.

Edworthy, A.B., Martin, K., 2013. Persistence of tree cavities used by cavity-nesting vertebrates declines in harvested forests. J. Wildl. Manage. 77, 770-776.

Garber, S.M., Brown, J.P., Wilson, D.S., Maguire, D.A., Heath, L.S., 2005. Snag longevity under alternative silvicultural regimes in mixed-species forests of central Maine. Can. J. For. Res. $35,787-796$.

Hagar, J.C., McComb, W.C., Emmingham, W.H., 1996. Bird communities in commercially thinned and unthinned Douglas-fir stands of western Oregon. Wildl. Soc. Bull. 24, 353-366.

Homyack, J.A., Paxton, B.J., Wilson, M.D., Watts, B.D., Miller, D.A., 2011. Snags and cavitynesting birds within intensively managed pine stands in eastern North Carolina, USA. South. J. Appl. For. 35, 148-165.

Husch, B., C.I. Miller, T.W. Beers, 1993. Forest Mensuration, third ed. Krieger Publ. Co., Malabar, FL.

Kilgo, J.C., Blake, J.I. (Eds.), 2005. Ecology and management of a forested landscape: fifty years on the Savannah River Site. Island Press, Covelo, CA. 
Kilgo, J.C., Vukovich, M.A., 2014. Can snag creation benefit a primary cavity nester: response to an experimental pulse in snag abundance. Biological Conservation 171, 21-28.

Kline, R.B, 1998. Principles and practice of structural equation modeling. Guilford Publishing, New York.

Kroll, A.J. Lacki, M.J., Arnett, E.B., 2012. Research needs to support management and conservation of cavity-dependent birds and bats on forested landscapes in the Pacific Northwest. West. J. Appl. For. 27, 128-136.

Land, D., Marion, W.R., O'Meara, T.E., 1989. Snag availability and cavity nesting birds in slash pine plantations. J. Wildl. Manage. 53, 1165-1171.

Lohr, S.M., Gauthreaux, S.A., Kilgo, J.C., 2002. Importance of coarse woody debris to avian communities in loblolly pine forests. Conservation Biology 16, 767-777.

Marchetti, M., 2004. Monitoring indicators of forest biodiversity in Europe. EFI Proceed. 51. European Forest Institute. Joenssu, FI. 526 p.

McComb, W.C., Bonney, S.A., Sheffield, R.M., Cost, N.D., 1986. Snag resources in Floridaare they sufficient for average populations of primary cavity nesters? Wildl. Soc. Bull. 14, $40-48$.

Menges, E.S., Deyrup, M.A., 2001. Postfire survival in south Florida slash pine: interacting effects of fire intensity, fire season, vegetation, burn size, and bark beetles. Int. J. Wildl.Fire $10,53-63$.

Millspaugh, J., Thompson, F., 2008. Models for planning wildlife conservation in large landscapes. Academic Press, New York, 720 pp.

Moorman, C. E., Russell, K.R., Sabin, G.R., Guynn, D.C., 1999. Snag dynamics and cavity occurrence in the South Carolina piedmont. For. Ecol. Manage. 118, 37-48. 
Muthén, L. K., Muthén, B.O., 2011. Mplus User's Guide, 6th ed. Muthén \& Muthén, Los Angeles, CA.

Ohmann, J.L., McComb, W.C., Zumrawi, A.A., 1994. Snag abundance for primary cavity nesting birds on nonfederal forest lands in Oregon and Washington. Wildl. Soc. Bull. 22, 607-620.

Outcalt, K.W., 2008. Lightening, fire and longleaf pine: using natural disturbance to guide management. For. Ecol. Manage. 255, 3351-3359.

Parresol, B.R., Blake, J.I., 2010. Savannah River Site 2010 Vegetation Inventory: Phase II Design Document and Contract Specifications. June, 2010. USDA Forest Service, New Ellenton, SC.

Parresol, B.R., Blake, J.I., Thompson, A., 2012. Effects of overstory composition and prescribed fire on fuel loading across a heterogeneous managed landscape in the southeastern USA. For. Ecol. Manage. 273, 29-42.

Petola, H.M., 2006. Mechanical stability of trees under static loads. Amer. J. Bot. 93, 1501-1511.

Rosenberg, D.K., Fraser, J.D., Stauffer, D.F., 1988. Use and characteristics of snags in young and old forest stands in southwest Virginia. For. Sci. 34, 224-228.

SAS Institute Inc., 2004. SAS/STAT® 9.1 user’s guide. Cary, NC: SAS Institute Inc.

Sullivan, B.T., Fettig, C.J., Otrosina, W.J., Dalusky, M.J., Berisford, C.W., 2003. Association between severity of prescribed burns and subsequent activity of conifer-infesting beetles in stands of longleaf pine. For. Ecol. Manage. 185, 327-340.

Wade, D.D, Johansen, R.W., 1986. Effects of fire on southern pine: observations and recommendations. USDA For. Ser. Gen. Tech. Rep. SE-41, Asheville, NC. 14 pp. 
Woodall, C.W., Miles, P.D., Vissage, J.S., 2005. Determining maximum stand density index in mixed species stands for strategic-scale stocking assessments. For. Ecol. Manage. 216, 367377.

Woudenberg, S.W., Conkling, B.L., O’Connell, B.M., LaPoint, E.B., Turner, J.A., Waddell, K.L., 2010. The forest inventory and analysis database: Database description and user's manual Version 4.0 for Phase 2. U.S. Department of Agriculture, Forest Service, Rocky Mountain Research Station, Gen. Tech Rep. RMRS-GTR-245, Fort Collins, CO.

Yaussy, D.A, Waldrop, T.A., 2010. Delayed mortality of eastern hardwoods after prescribed fire. in: Stanturf, J.A. (Ed.). Proc. 14th Biennial Southern Silvicultural Research Conference. USDA Forest Service, Gen. Tech. Rep. SRS-121, Asheville, NC, pp. 609-612.

Zarnoch, S.J., Vukovich, M.A., Kilgo, J.C., Blake, J.I., 2013. Snag characteristics and dynamics during intervals of low and high mortality in a managed loblolly pine forest. Can. J. For. Res. $43,817-825$. 


\section{List of Tables}

Table 1. The total number of sample points for each forest type and management history along with the number of sample points that contained at least one snag (All Snags) and one large snag $(\mathrm{DBH} \geq 25 \mathrm{~cm})$ (Large Snag).

Table 2. Means and 95\% confidence intervals for the data used in the logistic model and path analysis by forest type used to construct models of snag occurrence at the Savannah River Site, South Carolina, USA. The number of point samples in the path analysis was reduced to normalize the fire index $(F I)$ variable. Age and Site Index values represent the original values rescaled by dividing by 100 .

Table 3. All direct effects (standard errors) [p-vlaues] obtained from the snag occurrence path models for the loblolly pine, longleaf pine, mixed pine-hardwoods and hardwoods forest types. Significant effects $(\mathrm{p} \leq 0.10)$ are bolded.

Table 4. Direct, indirect and total effects (p-values) for the longleaf pine path models of snag occurrence for the all snag and large snag size classes.

Table 5. Regression coefficients (p-values) for the snag occurrence logistic model for each forest type. Variables with a dash line (------) indicate that the variable was not retained in the final backward stepwise modeling process. NM indicates variables that were not candidate variables for consideration in the model. $D_{q m d}$ is the quadratic mean diameter and $A_{q m d}$ is the effective plot size computed from equation 7. 


\section{List of Figures}

Figure 1. Path analysis model representing the initial hypothesis that prescribed fire would increase and thinning would decrease snag occurrence. Causal pathways and their direction are represented by arrows with one point while arrows with two points indicate covariances between exogenous variables. Thinning paths are represented as dashed lines and apply only to loblolly pine and longleaf pine forest types. Each path is represented by a two letter symbol.

Figure 2. The revised path analysis model for the longleaf pine forest type reflecting the stand age by residual stand density index interaction (AGE $x$ RSDI) observed in the logistic model. Causal pathways and their direction are represented by arrows with one point while arrows with two points indicate covariances between exogenous variables. Each path is represented by a two letter symbol.

Figure 3. The revised path analysis model for the hardwoods forest type reflecting the site index by fire index interaction (SI $x F I$ ) observed in the logistic model. Causal pathways and their direction are represented by arrows with one point while arrows with two points indicate covariances between exogenous variables. Each path is represented by a two letter symbol.

Figure 4. Likelihood index for the occurrence of one or more large snags (DBH $\geq 25 \mathrm{~cm})$ on 0.25 ha of the loblolly pine forest type in relation to stand age $(A G E)$ and the prescribed fire index $(F I)$ developed from the logistic model. $F I=0$ represents no fire history and $F I=2.0$ represents very frequent and recent fire treatments. 
Figure 5. Likelihood index for the occurrence of one or more large snags $(\mathrm{DBH} \geq 25 \mathrm{~cm})$ on 0.25 ha of the longleaf pine forest type in relation to stand age $(A G E)$ and the relative stand density index $(R S D I)$ developed from the logistic model. $R S D I=0.30,0.65$, and 1.0 represent low density, the lower limit for self- thinning and the upper limit, respectively.

Figure 6. Likelihood index for the occurrence of one or more large snags $(\mathrm{DBH} \geq 25 \mathrm{~cm}$ ) on 0.25 ha of the hardwoods forest type with a site index $(S I)$ of $20 \mathrm{~m}$ in relation to stand age $(A G E)$ and the prescribed fire index $(F I)$ developed from the logistic model. $F I=0$ represents no fire history and $F I=2.0$ represents very frequent and recent fire treatments.

Figure 7. Likelihood index for the occurrence of one or more large snags $(\mathrm{DBH} \geq 25 \mathrm{~cm})$ on 0.25 ha of the hardwoods forest type with a site index $(S I)$ of $30 \mathrm{~m}$ in relation to stand age $(A G E)$ and the prescribed fire index $(F I)$ developed from the logistic model. $F I=0$ represents no fire history and $F I=2.0$ represents very frequent and recent fire treatments. 
Table 1

\begin{tabular}{|c|c|c|c|c|c|c|}
\hline \multirow{2}{*}{$\begin{array}{l}\text { Forest } \\
\text { Type }\end{array}$} & \multicolumn{6}{|c|}{ Management History } \\
\hline & & $\begin{array}{l}\text { No Fire } \\
\text { No Thin }\end{array}$ & Thin Only & Fire Only & $\begin{array}{c}\text { Fire and } \\
\text { Thin }\end{array}$ & $\begin{array}{c}\text { Total } \\
\text { Sample } \\
\text { Points }\end{array}$ \\
\hline \multirow{3}{*}{$\begin{array}{l}\text { Loblolly } \\
\text { Pine }\end{array}$} & Sample Points & 77 & 38 & 263 & 131 & 509 \\
\hline & All Snags & 5 & 12 & 55 & 13 & 85 \\
\hline & Large Snags & 2 & 0 & 22 & 10 & 34 \\
\hline \multirow{3}{*}{$\begin{array}{l}\text { Longleaf } \\
\text { Pine }\end{array}$} & Sample Points & 52 & 12 & 216 & 109 & 389 \\
\hline & All Snags & 7 & 0 & 36 & 14 & 57 \\
\hline & Large Snags & 2 & 0 & 22 & 10 & 34 \\
\hline \multirow{3}{*}{$\begin{array}{l}\text { Mixed Pine- } \\
\text { Hardwoods }\end{array}$} & Sample Points & 59 & 2 & 158 & 14 & 233 \\
\hline & All Snags & 25 & 0 & 51 & 4 & 56 \\
\hline & Large Snags & 16 & 0 & 34 & 2 & 52 \\
\hline \multirow{3}{*}{ Hardwoods } & Sample Points & 164 & 1 & 156 & 2 & 323 \\
\hline & All Snags & 43 & 1 & 43 & 1 & 88 \\
\hline & Large Snags & 36 & 1 & 32 & 1 & 70 \\
\hline
\end{tabular}


Table 2

\begin{tabular}{|c|c|c|c|c|c|}
\hline Forest Type & & $\begin{array}{c}\text { Loblolly } \\
\text { Pine }^{\mathrm{a}}\end{array}$ & $\begin{array}{c}\text { Longleaf } \\
\text { Pine }^{\mathrm{b}}\end{array}$ & $\begin{array}{l}\text { Mixed Pine- } \\
\text { Hardwoods }\end{array}$ & Hardwoods \\
\hline Variable & Data & \multicolumn{4}{|c|}{ Mean and $95 \%$ Confidence Interval } \\
\hline \multirow{4}{*}{$\begin{array}{l}\text { Age/100 } \\
\text { (years) }\end{array}$} & Logistic & 0.390 & 0.427 & 0.575 & 0.684 \\
\hline & & $0.374,0.406$ & $0.405,0.450$ & $0.545,0.605$ & $0.655,0.712$ \\
\hline & Path & 0.408 & 0.451 & 0.580 & 0.698 \\
\hline & & $0.387,0.430$ & $0.425,0.476$ & $0.538,0.622$ & $0.658,0.738$ \\
\hline \multirow{4}{*}{$\begin{array}{l}\text { Site Index/100 } \\
\text { (m) }\end{array}$} & Logistic & 0.259 & 0.231 & 0.264 & 0.266 \\
\hline & & $0.255,0.262$ & $0.228,0.235$ & $0.259,0.269$ & $0.262,0.270$ \\
\hline & Path & 0.259 & 0.232 & 0.262 & 0.262 \\
\hline & & $0.254,0.263$ & $0.227,0.236$ & $0.255,0.268$ & $0.256,0.268$ \\
\hline \multirow{4}{*}{$\begin{array}{l}\text { RSDI } \\
\text { (see Eq. 4) }\end{array}$} & Logistic & 0.520 & 0.511 & 0.553 & 0.573 \\
\hline & & $0.500,0.540$ & $0.488,0.534$ & $0.529,0.577$ & $0.551,0.596$ \\
\hline & Path & 0.507 & 0.508 & 0.551 & 0.584 \\
\hline & & $0.482,0.533$ & $0.480,0.536$ & $0.519,0.583$ & $0.548,0.619$ \\
\hline \multirow{4}{*}{ Thin Index } & Logistic & 0.144 & 0.175 & NA & NA \\
\hline & & $0.117,0.171$ & $0.139,0.211$ & & \\
\hline & Path & 0.158 & 0.210 & NA & NA \\
\hline & & $0.120,0.196$ & $0.164,0.255$ & & \\
\hline \multirow{4}{*}{ Fire Index } & Logistic & 0.754 & 1.075 & 0.772 & 0.429 \\
\hline & & $0.667,0.842$ & $0.961,1.190$ & $0.640,0.904$ & $0.341,0.517$ \\
\hline & Path & 1.326 & 1.477 & 1.413 & 1.114 \\
\hline & & $1.209,1.444$ & $1.348,1.607$ & $1.237,1.589$ & $0.943,1.284$ \\
\hline
\end{tabular}

${ }^{\mathrm{a}}$ The logistic sample size was 509 and the reduced path analysis sample size was 289 .

${ }^{\mathrm{b}}$ The logistic sample size was 389 and the reduced path analysis sample size was 283 .

${ }^{\mathrm{c}}$ The logistic sample size was 233 and the reduced path analysis sample size was 127 .

${ }^{\mathrm{d}}$ The logistic sample size was 323 and the reduced path analysis sample size was 124 . 
Table 3

\begin{tabular}{|c|c|c|c|c|c|c|c|c|c|c|c|c|}
\hline \multirow[t]{4}{*}{ Forest Type } & \multicolumn{12}{|c|}{ Standardized Path Model Coefficients, Standard Errors () and P-values [] Corresponding to Paths Identified in Figures 1, 2, 3} \\
\hline & \multicolumn{6}{|c|}{ Direct Effects on Snag Occurrence } & \multicolumn{6}{|c|}{ Other Direct Effects Between Variables } \\
\hline & SI & RSDI & Thin & Fire & $A G E$ & Interaction $^{\mathrm{a}}$ & SI & $A G E$ & $A G E$ & Thin & & \\
\hline & $O S$ & $O D$ & $O T$ & $O F$ & $O A$ & $O I$ & $D S$ & $D A$ & $F A$ & $D T$ & & \\
\hline \multirow{3}{*}{$\begin{array}{l}\text { Loblolly Pine } \\
\text { All Snags }\end{array}$} & -0.008 & -0.047 & -0.188 & 0.145 & 0.313 & -------- & -0.042 & -0.265 & 0.101 & -0.326 & & \\
\hline & $(0.083)$ & $(0.090)$ & $(0.105)$ & $(0.077)$ & $(0.080)$ & & $(0.055)$ & $(0.054)$ & 0.058) & $(0.051)$ & & \\
\hline & [0.919] & {$[0.601]$} & {$[0.073]$} & [0.061] & {$[0.000]$} & & {$[0.446]$} & {$[0.000]$} & {$[0.082]$} & {$[0.000]$} & & \\
\hline \multirow{4}{*}{$\begin{array}{l}\text { Loblolly Pine } \\
\text { Large Snags }\end{array}$} & 0.041 & -0.185 & -0.107 & 0.205 & 0.368 & -------- & -0.042 & -0.265 & 0.101 & -0.326 & & \\
\hline & $(0.092)$ & (0.108) & $(0.108)$ & $(0.088)$ & (0.089) & & $(0.055)$ & $(0.054)$ & $(0.058)$ & $(0.051)$ & & \\
\hline & $0.654]$ & [0.087] & {$[0.322]$} & [0.019] & {$[0.000]$} & & [0.446] & {$[0.000]$} & [0.082] & {$[0.000]$} & & \\
\hline & & & & & & & & & & & $A G E(I A)$ & $R S D I(I D)$ \\
\hline \multirow{3}{*}{$\begin{array}{l}\text { Longleaf Pine } \\
\text { All Snags }\end{array}$} & -0.024 & -0.322 & -0.045 & -0.009 & 0.082 & 0.150 & -0.120 & -0.204 & 0.111 & -0.368 & -0.003 & -0.340 \\
\hline & $(0.085)$ & (0.109) & $(0.088)$ & $(0.081)$ & $(0.087)$ & $(0.095)$ & $(0.052)$ & $(0.053)$ & $(0.059)$ & $(0.050)$ & $(0.058)$ & $(0.055)$ \\
\hline & {$[0.781]$} & {$[0.003]$} & [0.611] & [0.909] & [0.347] & [0.116] & {$[0.021]$} & {$[0.000]$} & {$[0.059]$} & {$[0.000]$} & {$[0.960]$} & {$[0.000]$} \\
\hline \multirow{3}{*}{$\begin{array}{l}\text { Longleaf Pine } \\
\text { Large Snags }\end{array}$} & 0.050 & -0.413 & -0.043 & 0.002 & 0.159 & 0.0298 & -0.120 & -0.204 & 0.111 & -0.368 & -0.003 & -0.340 \\
\hline & $(0.088)$ & (0.112) & $(0.089)$ & $(0.084)$ & $(\mathbf{0 . 0 9 0})$ & $(0.086)$ & $(0.052)$ & $(\mathbf{0 . 0 5 3})$ & (0.059) & $(\mathbf{0 . 0 5 0})$ & $(0.058)$ & $(\mathbf{0 . 0 5 5 )}$ \\
\hline & {$[0.572]$} & {$[0.000]$} & [0.627] & [0.978] & [0.077] & [0.001] & [0.021] & {$[0.000]$} & [0.059] & {$[0.000]$} & {$[0.960]$} & [0.000] \\
\hline \multirow{3}{*}{$\begin{array}{l}\text { Mixed Pine- } \\
\text { Hardwoods } \\
\text { All Snags }\end{array}$} & -0.008 & 0.029 & ------- & -0.131 & 0.289 & -------- & 0.085 & 0.086 & 0.051 & -------- & -------- & -------- \\
\hline & $(0.108)$ & $(0.107)$ & & $(0.103)$ & (0.105) & & $(0.090)$ & $(0.090)$ & $(0.089)$ & & & \\
\hline & [0.939] & {$[0.735]$} & & {$[0.206]$} & {$[0.006]$} & & {$[0.341]$} & [0.338] & {$[0.566]$} & & & \\
\hline \multirow{4}{*}{$\begin{array}{l}\text { Mixed Pine- } \\
\text { Hardwoods } \\
\text { Large Snags }\end{array}$} & 0.019 & -0.046 & -------- & -0.119 & 0.249 & -------- & 0.085 & 0.086 & 0.051 & -------- & -------- & -------- \\
\hline & $(0.122)$ & $(0.123)$ & & $(0.116)$ & ((0.119) & & $(0.090)$ & $(0.090)$ & (0.089) & & & \\
\hline & [0874] & [0.709] & & [0.304] & {$[0.037]$} & & [0.341] & [0.338] & {$[0.566]$} & & & \\
\hline & & & & & & & & & & & Fire $(I F)$ & $S I(I S)$ \\
\hline \multirow{3}{*}{$\begin{array}{l}\text { Hardwoods } \\
\text { All Snags }\end{array}$} & -0.093 & 0.037 & & -0.205 & 0.251 & -0.151 & -0.039 & 0.175 & -0.071 & -------- & -0.021 & -0.054 \\
\hline & $(0.108)$ & $(0.105)$ & & $(0.116)$ & (0.111) & $(0.112)$ & (0.089) & $(0.087)$ & (0.089) & & $(0.091)$ & $(0.091)$ \\
\hline & {$[0.378]$} & {$[0.726]$} & & [0.077] & {$[0.024]$} & [0.177] & [0.657] & {$[0.045]$} & [0.429] & & [0.817] & {$[0.550]$} \\
\hline \multirow{3}{*}{$\begin{array}{l}\text { Hardwoods } \\
\text { Large Snags }\end{array}$} & -0.121 & -0.045 & -------- & -0.264 & 0.388 & -0.266 & -0.039 & 0.175 & -0.071 & -------- & -0.021 & -0.054 \\
\hline & $(0.114)$ & $(0.106)$ & & (0.127) & (0.114) & $(0.110)$ & $(0.089)$ & $(0.087)$ & (0.089) & & $(0.091)$ & $(0.091)$ \\
\hline & [0.288] & [0.673] & & [0.038] & {$[0.001]$} & {$[0.016]$} & {$[0.657]$} & {$[0.045]$} & [0.429] & & [0.817] & {$[0.055]$} \\
\hline
\end{tabular}

${ }^{a}$ The $O I$ path is the $A G E \times R S D I$ interaction for longleaf pine and the $S I x F I$ interaction for hardwoods. 
Table 4

\begin{tabular}{|c|c|c|c|}
\hline \multicolumn{4}{|c|}{ Standardized Coefficients for Path Effects (p-values) } \\
\hline $\begin{array}{c}\text { Snag Size } \\
\text { Class } \\
\end{array}$ & Direct Effect & Indirect Effect & Total Effect \\
\hline \multicolumn{4}{|c|}{ Site Index } \\
\hline All & $\begin{array}{l}-0.024 \\
(0.781)\end{array}$ & $\begin{array}{c}0.044 \\
(0.069)\end{array}$ & $\begin{array}{c}0.020 \\
(0.804)\end{array}$ \\
\hline Large & $\begin{array}{c}0.050 \\
(0.572)\end{array}$ & $\begin{array}{c}0.065 \\
(0.062) \\
\end{array}$ & $\begin{array}{c}0.115 \\
(0.231)\end{array}$ \\
\hline \multicolumn{4}{|c|}{ Thin Index } \\
\hline All & $\begin{array}{l}-0.045 \\
(0.611)\end{array}$ & $\begin{array}{c}0.136 \\
(0.006)\end{array}$ & $\begin{array}{c}0.091 \\
(0.278)\end{array}$ \\
\hline Large & $\begin{array}{c}-0.043 \\
(0.627)\end{array}$ & $\begin{array}{c}0.189 \\
(0.004)\end{array}$ & $\begin{array}{c}0.146 \\
(0.112)\end{array}$ \\
\hline \multicolumn{4}{|c|}{ Age } \\
\hline All & $\begin{array}{c}0.082 \\
(0.347) \\
\end{array}$ & $\begin{array}{c}0.064 \\
(0.031) \\
\end{array}$ & $\begin{array}{l}0.126 \\
0.102\end{array}$ \\
\hline Large & $\begin{array}{c}0.159 \\
(0.077)\end{array}$ & $\begin{array}{c}0.104 \\
(0.025)\end{array}$ & $\begin{array}{c}0.263 \\
(0.026)\end{array}$ \\
\hline
\end{tabular}


Table 5

\begin{tabular}{|c|c|c|c|c|c|c|c|c|}
\hline \multirow{2}{*}{$\begin{array}{l}\text { Forest Type } \\
\text { Snag Class }\end{array}$} & \multicolumn{2}{|c|}{ Loblolly Pine } & \multicolumn{2}{|c|}{ Longleaf Pine } & \multicolumn{2}{|c|}{$\begin{array}{l}\text { Mixed Pine- } \\
\text { Hardwoods }\end{array}$} & \multicolumn{2}{|c|}{ Hardwoods } \\
\hline & All & Large & All & Large & All & Large & All & Large \\
\hline Variables & \multicolumn{8}{|c|}{ Regression Coefficients ( $p$-values) } \\
\hline Intercept & $\begin{array}{l}-6.924 \\
(0.002) \\
\end{array}$ & $\begin{array}{l}-9.632 \\
(0.003) \\
\end{array}$ & $\begin{array}{l}-1.140 \\
(0.154) \\
\end{array}$ & $\begin{array}{c}4.065 \\
(0.240) \\
\end{array}$ & $\begin{array}{c}3.509 \\
(0.347) \\
\end{array}$ & $\begin{array}{c}4.388 \\
(0.296) \\
\end{array}$ & $\begin{array}{l}-2.856 \\
(0.008) \\
\end{array}$ & $\begin{array}{l}-4.182 \\
(0.001) \\
\end{array}$ \\
\hline$A G E$ (years) & $\begin{array}{c}0.109 \\
(0.017) \\
\end{array}$ & $\begin{array}{c}0.147 \\
(0.014) \\
\end{array}$ & $\begin{array}{l}-0.028 \\
(0.100) \\
\end{array}$ & $\begin{array}{l}-0.053 \\
(0.007) \\
\end{array}$ & $\begin{array}{c}0.030 \\
(0.000) \\
\end{array}$ & $\begin{array}{c}0.028 \\
(0.004) \\
\end{array}$ & -------- & $\begin{array}{c}0.015 \\
(0.0078) \\
\end{array}$ \\
\hline$S I(\mathrm{~m})$ & $\begin{array}{c}0.161 \\
(0.063) \\
\end{array}$ & $\begin{array}{c}0.254 \\
(0.036) \\
\end{array}$ & -------- & $\begin{array}{l}-0.145 \\
(0.248) \\
\end{array}$ & $\begin{array}{r}-0.243 \\
(0.093) \\
\end{array}$ & $\begin{array}{l}-0.280 \\
(0.082) \\
\end{array}$ & $\begin{array}{c}0.071 \\
(0.071) \\
\end{array}$ & $\begin{array}{c}0.070 \\
(0.102) \\
\end{array}$ \\
\hline$R S D I$ & ------- & $\begin{array}{l}-1.684 \\
(0.034) \\
\end{array}$ & $\begin{array}{l}-2.164 \\
(0.147)\end{array}$ & $\begin{array}{l}-18.959 \\
(0.008) \\
\end{array}$ & $\begin{array}{r}-11.728 \\
(0.075)\end{array}$ & $\begin{array}{r}-16.031 \\
(0.035) \\
\end{array}$ & --------- & ------- \\
\hline$A G E * S I$ & $\begin{array}{l}-0.003 \\
(0.058)\end{array}$ & $\begin{array}{l}-0.005 \\
(0.047)\end{array}$ & -------- & ------- & --------- & ------- & -------- & ------- \\
\hline$A G E * R S D I$ & ------- & -------- & $\begin{array}{c}0.070 \\
(0.032)\end{array}$ & $\begin{array}{c}0.145 \\
(0.000)\end{array}$ & ------- & -------- & -------- & ------- \\
\hline$S I * R S D I$ & -------- & -------- & ------- & $\begin{array}{c}0.456 \\
(0.066)\end{array}$ & $\begin{array}{c}0.485 \\
(0.0530)\end{array}$ & $\begin{array}{c}0.610 \\
(0.032)\end{array}$ & -------- & ------- \\
\hline$F I$ & $\begin{array}{c}0.272 \\
(0.016)\end{array}$ & $\begin{array}{c}0.317 \\
(0.013)\end{array}$ & $\begin{array}{c}0.818 \\
(0.020)\end{array}$ & ------- & $\begin{array}{c}0.456 \\
(0.290)\end{array}$ & $\begin{array}{c}0.685 \\
(0.158)\end{array}$ & $\begin{array}{c}2.081 \\
(0.105)\end{array}$ & $\begin{array}{c}2.852 \\
(0.047)\end{array}$ \\
\hline$T I$ & $\begin{array}{l}------ \\
--1\end{array}$ & -------- & $\begin{array}{c}2.766 \\
(0.021) \\
\end{array}$ & $\begin{array}{c}2.613 \\
(0.055) \\
\end{array}$ & NM & NM & NM & NM \\
\hline$R S D I * F I$ & ---------- & -------- & $\begin{array}{l}-1.535 \\
(0.029) \\
\end{array}$ & -------- & -------- & & ------- & ------- \\
\hline$R S D I * T I$ & -------- & -------- & $\begin{array}{l}-9.485 \\
(0.019) \\
\end{array}$ & $\begin{array}{l}-8.237 \\
(0.073)\end{array}$ & NM & NM & NM & NM \\
\hline$A G E * F I$ & -------- & -------- & -------- & -------- & $\begin{array}{l}-0.011 \\
(0.082\end{array}$ & $\begin{array}{l}-0.013 \\
(0.070)\end{array}$ & -------- & ------- \\
\hline$S I * F I$ & - ------- & --------- & ----- & -------- & - & -------- & $\begin{array}{l}-0.084 \\
(0.094)\end{array}$ & $\begin{array}{l}-0.118 \\
(0.041)\end{array}$ \\
\hline Re-scaled $r^{2}$ & 0.081 & 0.145 & 0.098 & 0.163 & 0.129 & 0.105 & 0.022 & 0.066 \\
\hline$D_{q m d}(\mathrm{~cm})$ & 31.39 & 38.56 & 31.34 & 38.69 & 38.58 & 45.30 & 42.62 & 49.76 \\
\hline$A_{q m d}$ (ha) & 0.0346 & 0.0520 & 0.0363 & 0.0554 & 0.0513 & 0.0705 & 0.0624 & 0.0850 \\
\hline
\end{tabular}


Figure 1

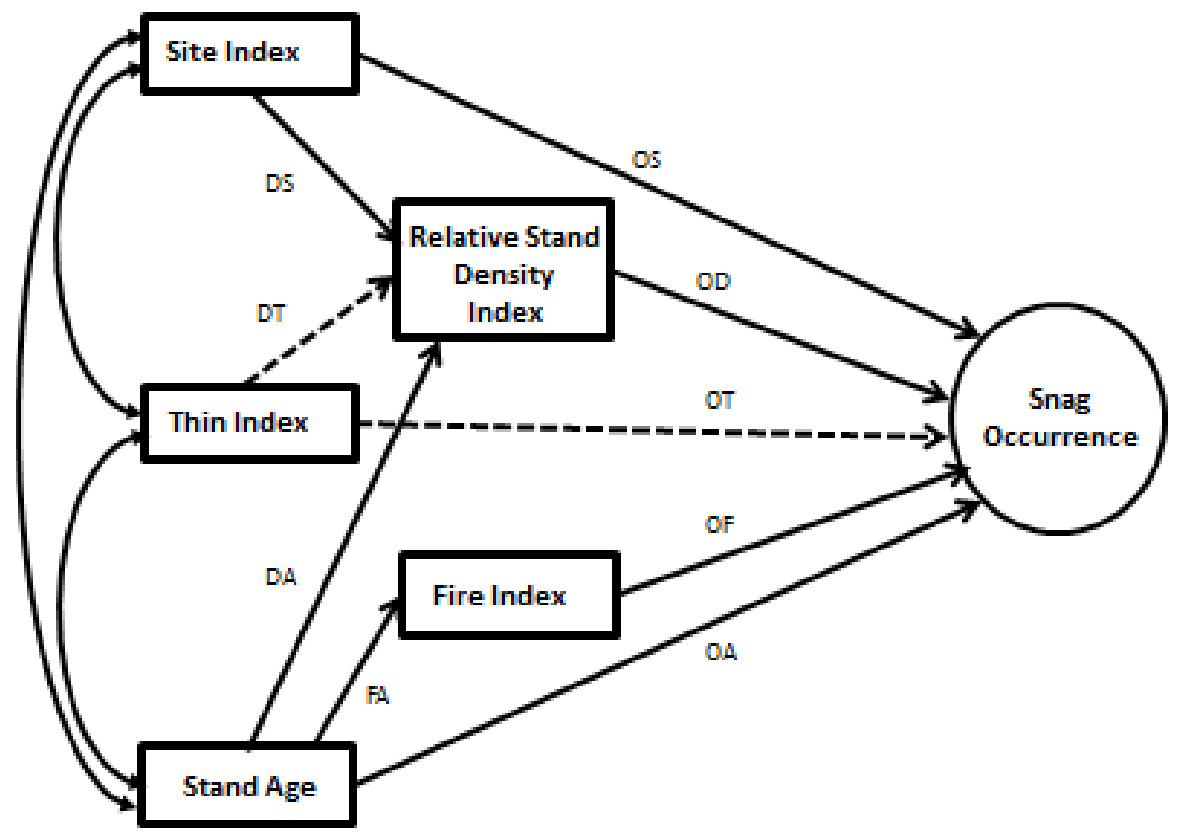

Figure 2

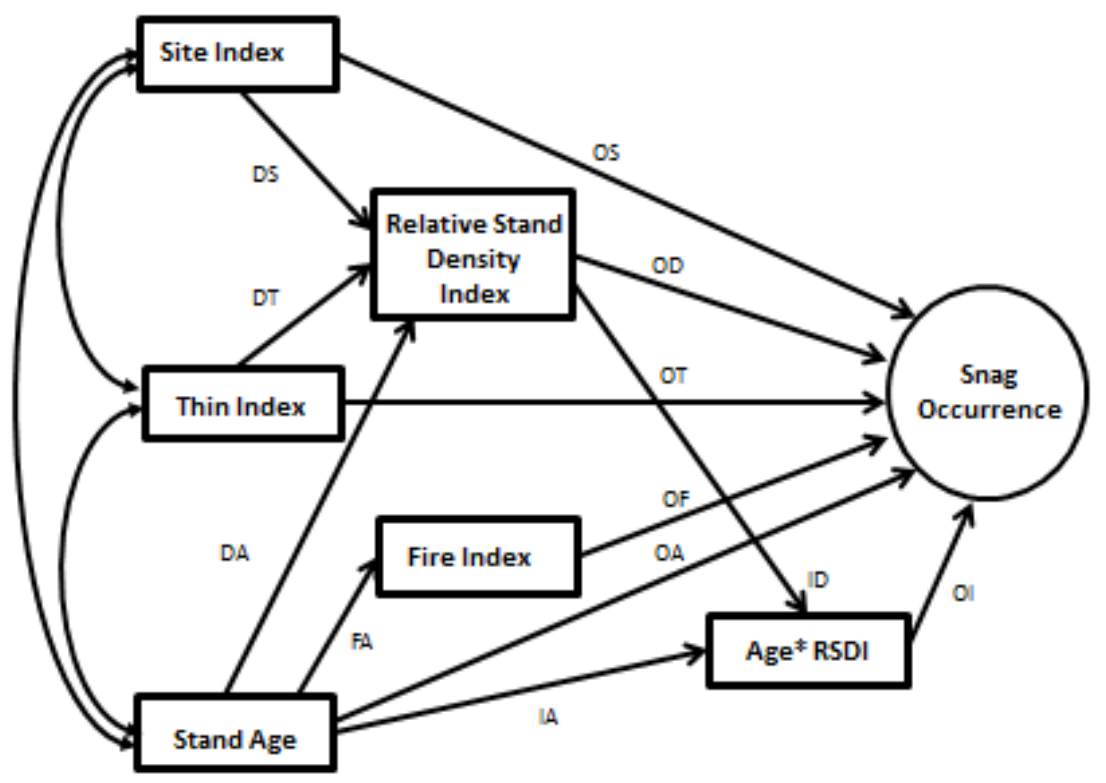


Figure 3

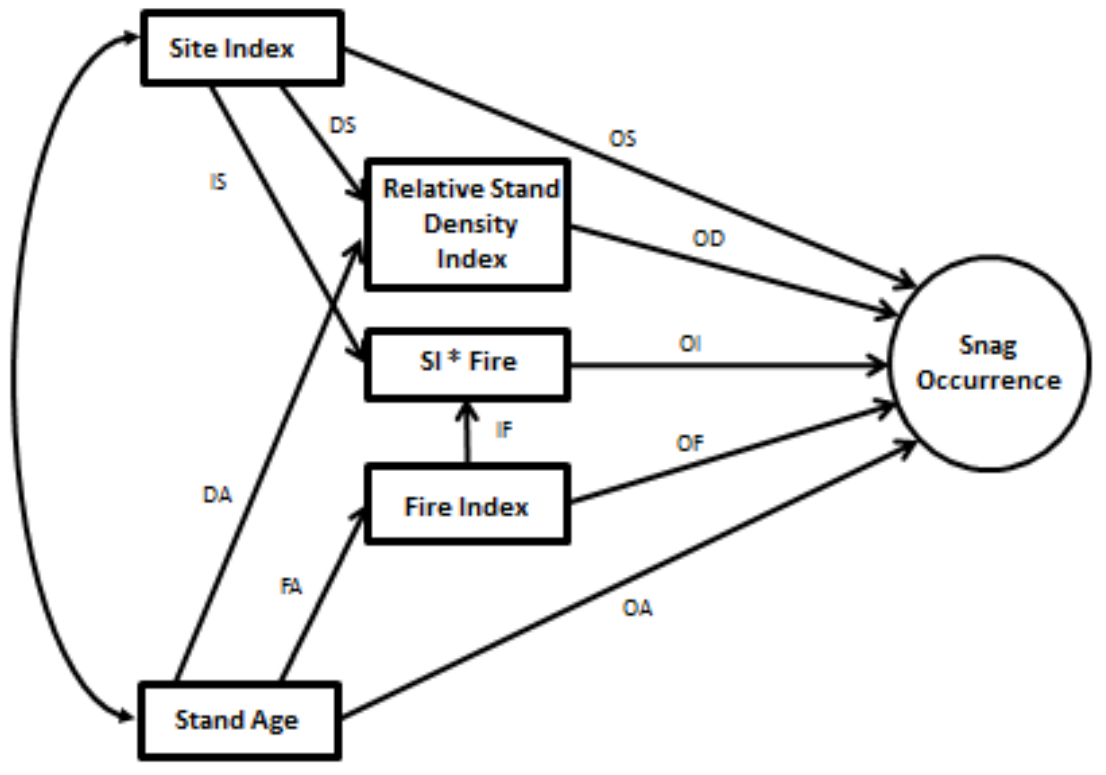


Figure 4

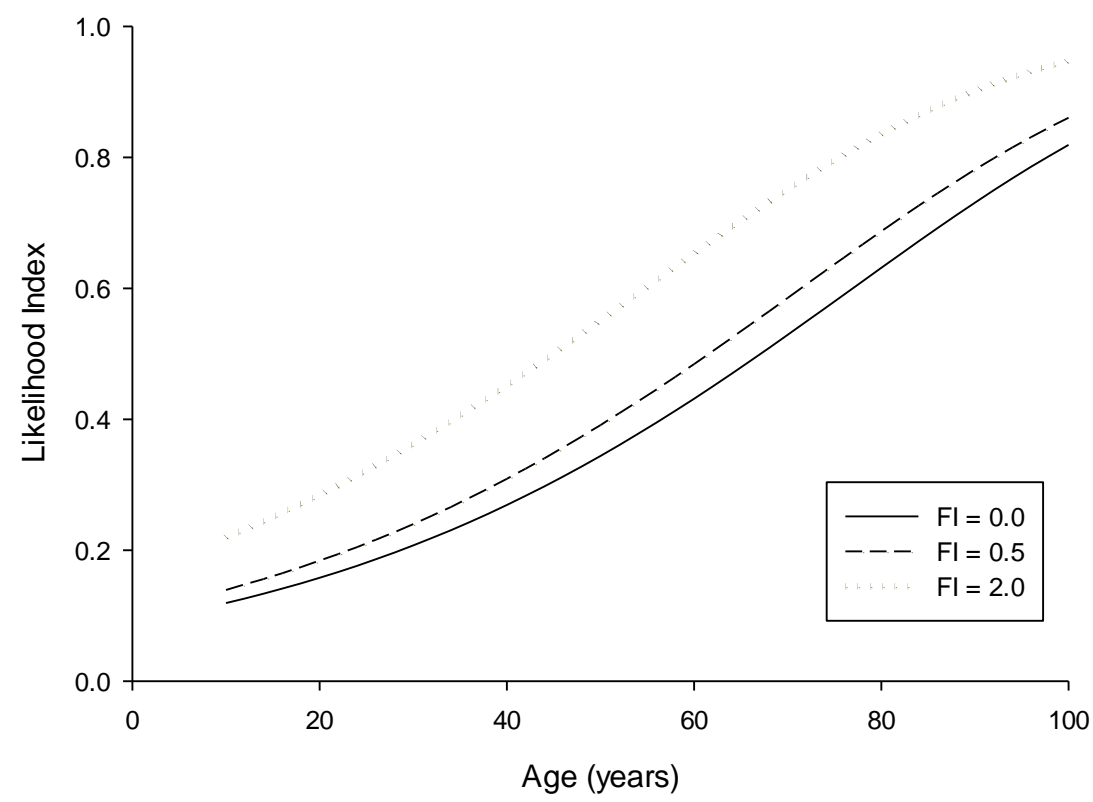


Figure 5

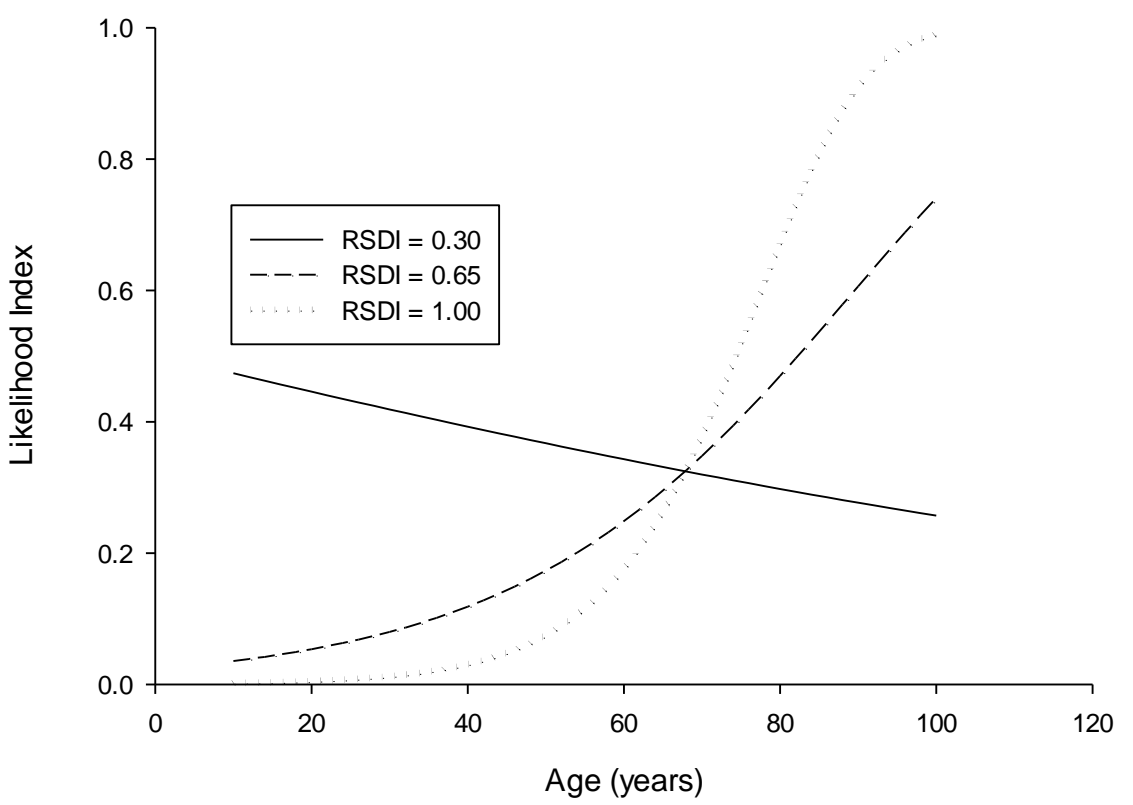


Figure 6

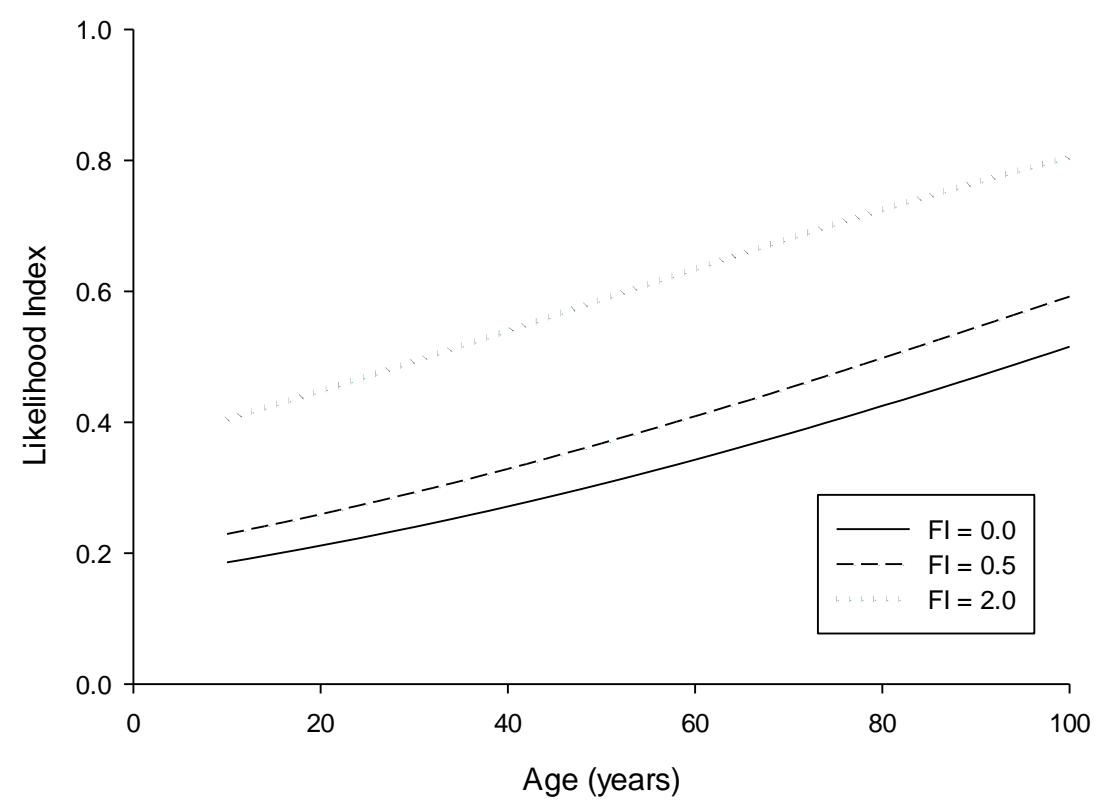


Figure 7

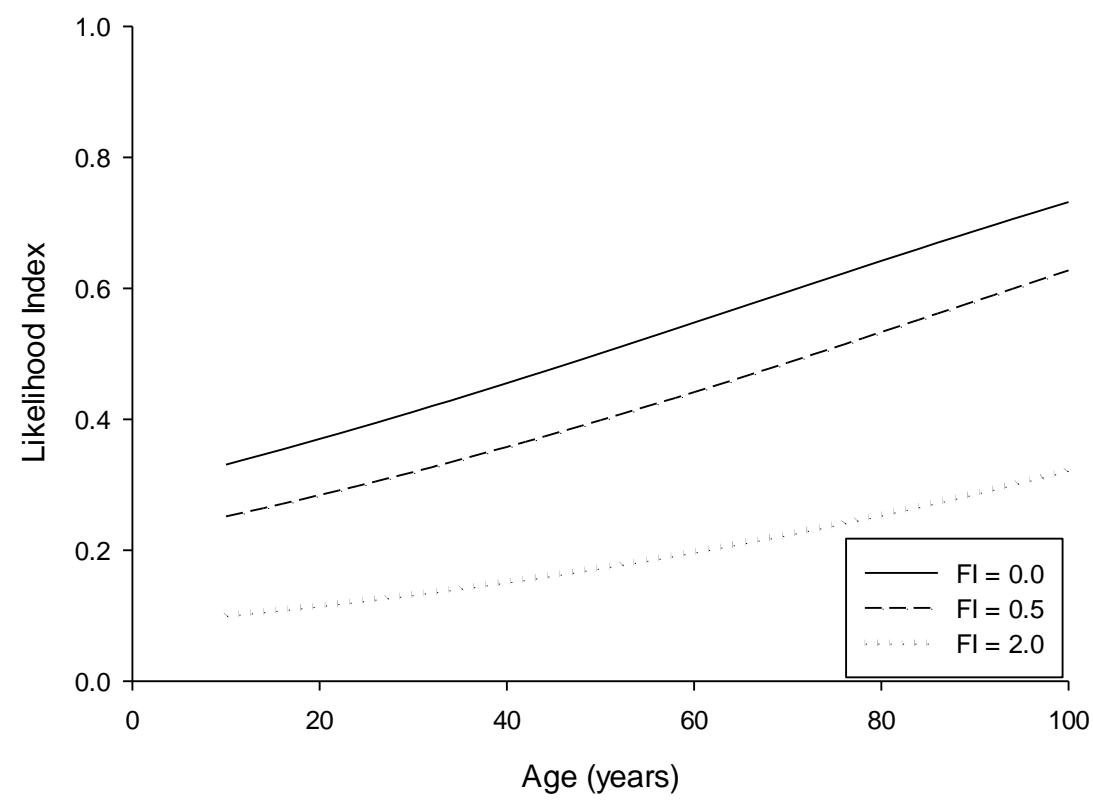

